
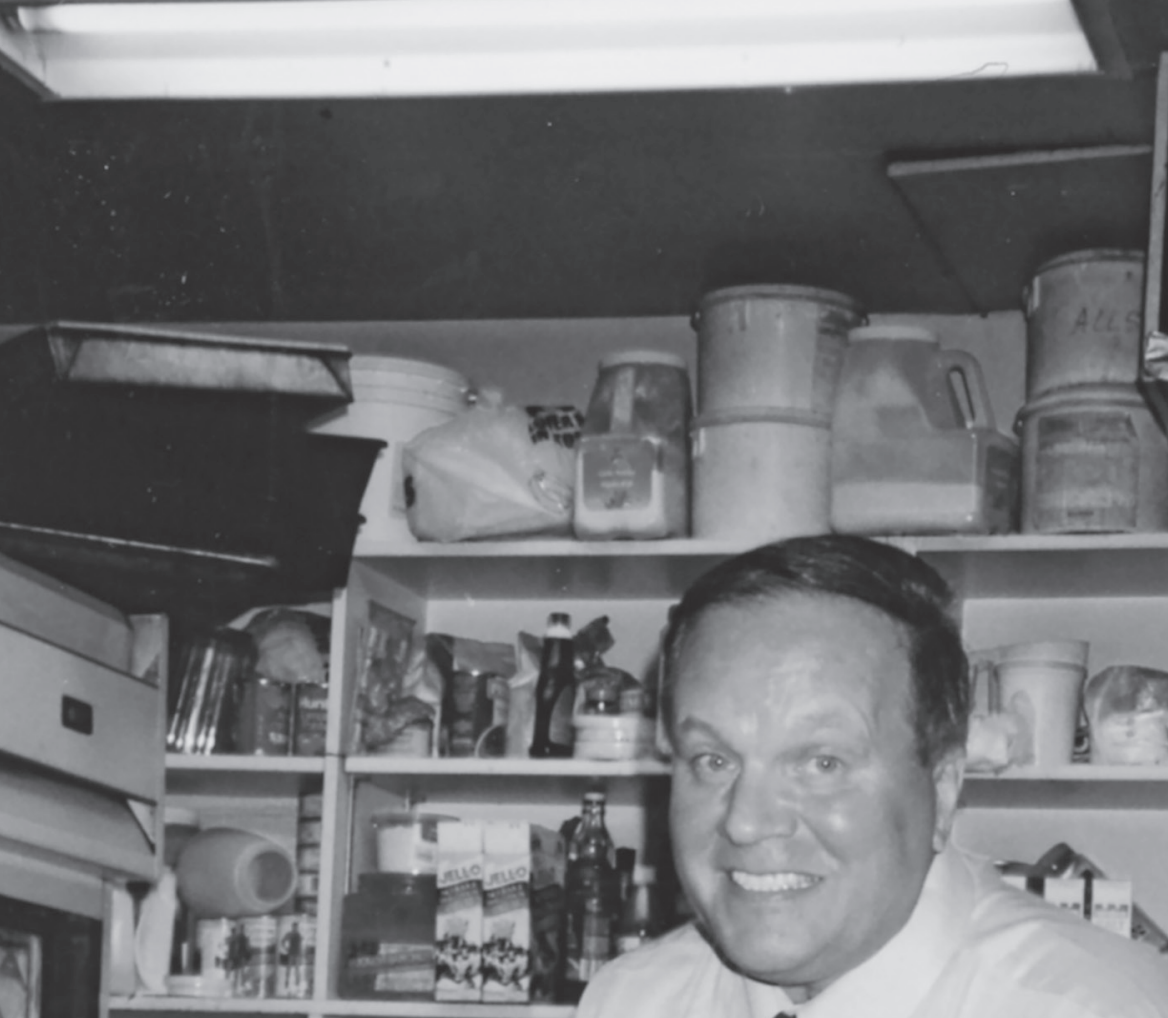

का
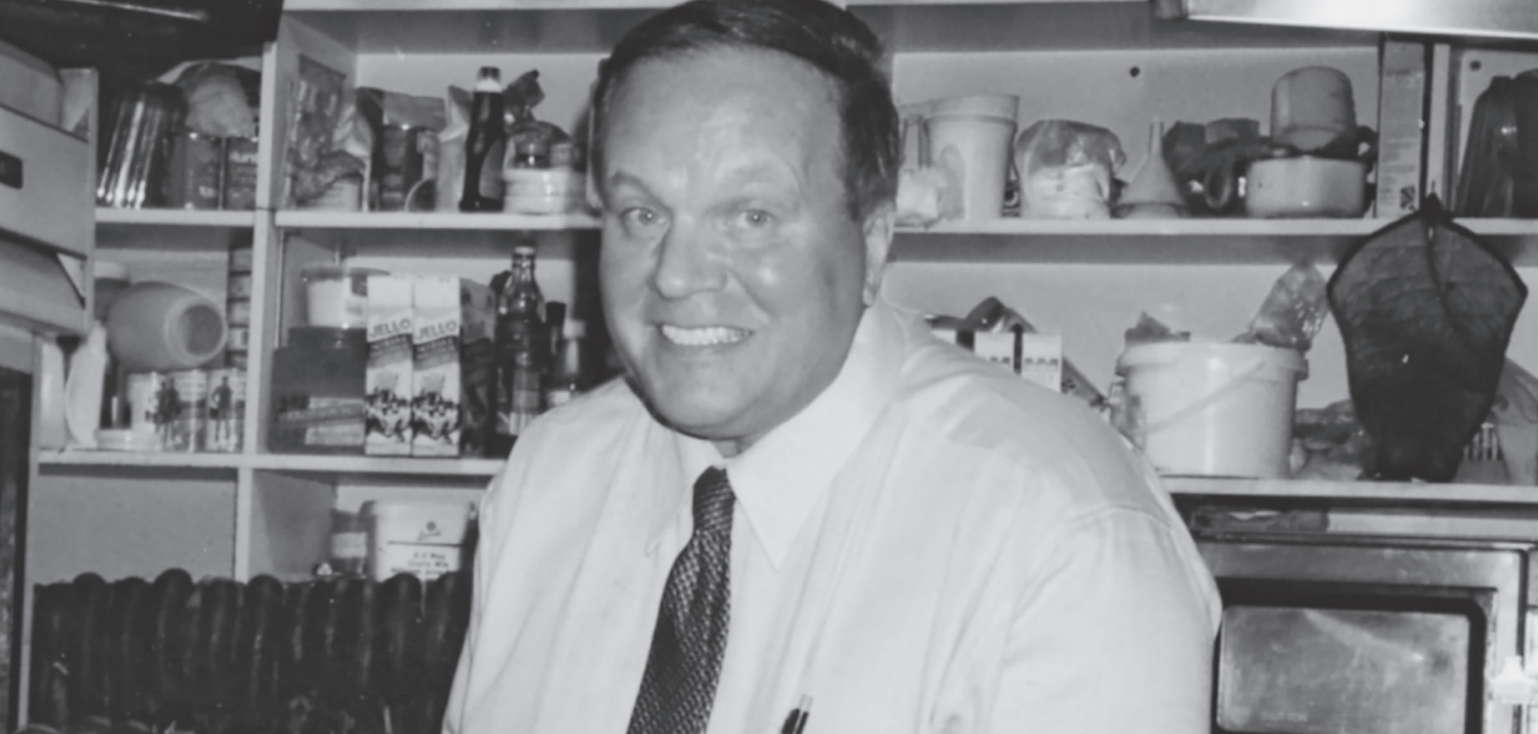

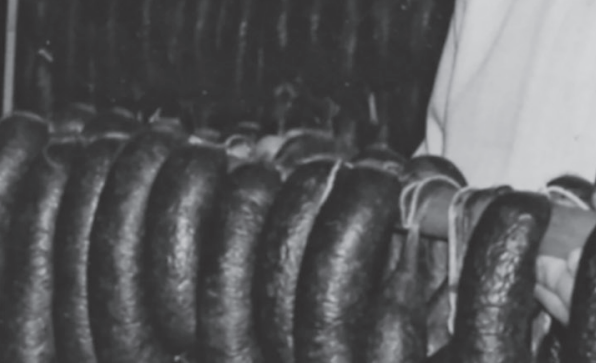

(19) $1 \sqrt{2}$

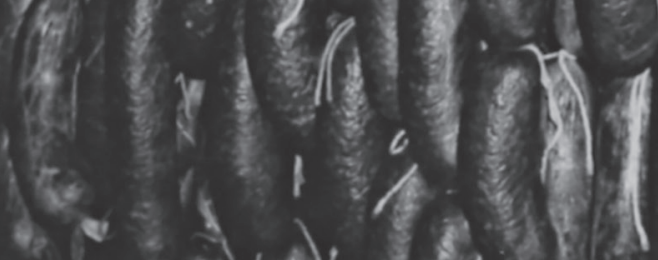

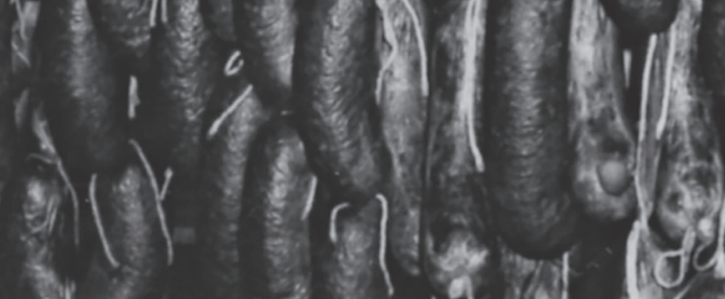
s.
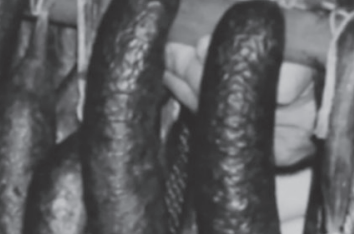

॥

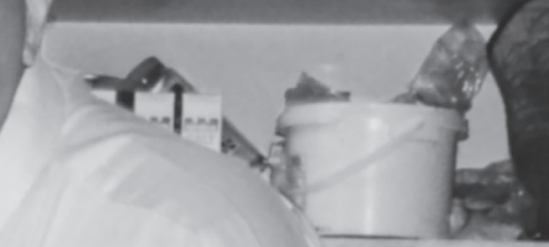

है

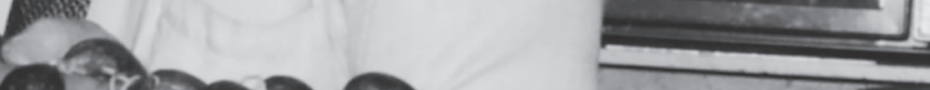




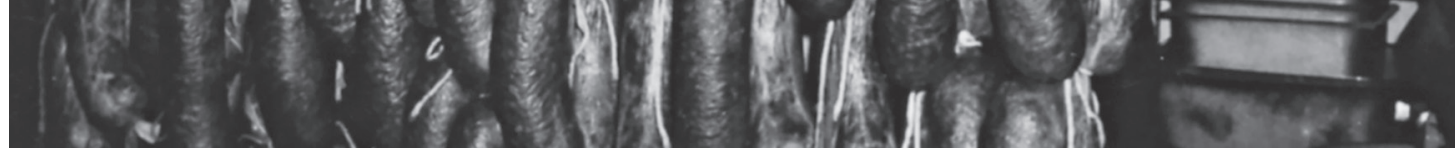

ERMi aastaraamat 60 (2017), Ik 94-115

DOI: 10.33302 /ermar-2017-004

\section{Oma ja võõras toit: 1944. aasta pagulaste toidukogemused ERMi allikate põhjal}

Riina Reinvelt

1944. aasta suvel ja sügisel põgenes Nõukogude vägede eest üle Läänemere Soome, Rootsi ja Saksamaale tuhandeid eestlasi. Teise maailmasõja kestel lahkus läände 70000 - 90000 inimest, neist Saksamaale jõudis umbes 50000 (Kumer-Haukanõmm 2009: 17) ja Rootsi ligi 28000 eestimaalast, sh 6000-7000 rannarootslast (Raag 2009: 56). Otsus astuda paati või laevale muutis paljude inimeste ja perede elu. Mere ületamine kujunes piiriks Eestis ja välismaal elatud elu vahel.

Siiani on peamiselt uuritud pagulaste põgenemislugusid, organisatsioonide tegevust, keelekasutust ja kultuuri (teater, muusika, kirjandus jne). Vähem on uurimusi, mis kajastaks pagulaste argipäeva. Kohanemist uues keskkonnas ja kultuurikontakte on käsitlenud Aivar Jürgenson (2011) ja Maarja Merivoo-Parro (2010). Kultuuriidentiteedile kodukujunduse kaudu keskendus magistritöös Jane Kalajärv (2011). Selles aastaraamatus leidub Aivar Jürgensoni artikkel „Eestlaste toidukultuur võõrsil“ (lk 62-93). Käesolevas loos käsitlen Eesti Rahva Muuseumi kirjasaatjate vastuste arhiivi ja etnograafilise arhiivi materjalide põhjal pagulaste esmaseid kokkupuuteid uute maitsetega 1940.-50. aastatel ning eestipärase toidu osa eestluse hoidmisel välismaal.

\section{Allikad}

Eesti läänepoolse diasporaa materjalide laekumine Eesti muuseumidesse algas 1988. aastal, mil kontaktid Nõukogude Eesti ja välismaal elavate eesti kogukondade vahel muutusid järjest aktiivsemaks. Eesti Rahva Muuseum on väliseestlaste teemaga tegelenud alates sellest ajast, kuid esimesel kümnel aastal oli materjalide laekumine pigem juhuslik ja esemekeskne. Mälestuste ja arhiivimaterjalide kogumisega on muuseumis järjepidevalt tegeletud 1998. aastast, mil saadeti laiali esimene küsitlusleht pealkirjaga „Põgenemine kodumaalt. Esimene aastakümme paguluses“ (Saar 1998), millele järgnes neli aastat hiljem järgmine küsimustik „Väliseestla- 
sed 1955-2000“ (Saar 2002). Mõlemas oli rubriik „Kodu ja pere“, kus leidus ka üks toiduharjumuste kohta päriv alalõik. Esimeses küsitluslehes küsiti: „Missugune oli teie pere toit? Kas ja millal sõite eestipäraseid toite? Missugused tundusid teile kohalike elanike toidud ja toitumistavad? Mida oli neis erinevat võrreldes kodumaaga?“ Teises küsitluslehes, mis puudutas 45 aasta pikkust välismaal elatud perioodi, uuriti: „Missugune oli teie pere toit? Kas ja millal sõite eestipäraseid toite? Mida?" Küsitluslehtede levitamisel olid abiks väliseesti ajalehed, kohalikud seltsid ja Eesti majad. Esimesele, peamiselt põgenemise kohta käivale küsitluslehele tuli vastuseid 150, teisele 50. Sellest võib järeldada, et kirjutamist põgenemisest, mis tõi kaasa suure elumuutuse ja oli murranguks inimeste elus, peeti olulisemaks kui hilisemal asukohamaal saadud kogemuste vahendamist. Mõlemale küsitluslehele vastanud inimesed olid toiduküsimuse puhul enamasti väga napisõnalised, piirdudes vastustega: „Jah, eestipärane“, „Sõime eestipäraseid toite pühadel ja sünnipäevadel“. Oli ka üksikuid pikemaid kirjeldusi selle kohta, mis see eestipärane toit on ja kust seda sai või kuidas valmistati.

Esimesed välitööd väliseestlaste intervjueerimiseks viis muuseumi teadur Edgar Saar läbi Rootsis, Inglismaal, Ameerikas, Saksamaal, Taanis ja Belgias aastatel 1999-2001. Kokku küsitles ta 139 inimest ja tekstina on välitööde tulemusel ERMi etnograafilises arhiivis talletatud 1580 lehekülge (EA 240, 250, 260, 262, 263, 264, 277). Küsitlemisel tugines Saar paljuski enda koostatud esimesele küsitluslehele „Põgenemine kodumaalt ja esimene aastakümme paguluses", kuid ei järginud seda punkt-punktilt. Kohati tundis ta siiski ka huvi toidutavade vastu, kuid pigem oli see kõrvaline teema ja vastajad ei peatunud sellel kuigi pikalt.

Väikeste intervallidega on väliseesti mälestuste kogumine muuseumis kestnud tänaseni. Olen selle teemaga ise seotud olnud 1996. aastast, mil intervjueerisin Ameerika eestlasi, millele järgnesid välitööd Rootsis, Kanadas ja Austraalias. Aastatel 2012-2013 tegime videointervjuusid Ameerikas, Kanadas ja Rootsis seoses muuseumi püsinäituse ettevalmistamisega. Need olid eelkõige mõeldud elulooliste mälestuste kogumiseks. Toiduteema ei olnud üldiselt jutustajate jaoks valdkond, millest nad oleks pidanud vajalikuks rääkida.

2012-2014 teostas Eesti Rahva Muuseum koos Torontos asuva Väliseesti Muuseumiga projekti „Eesti toiduärid Torontos“, mille käigus koguti materjali eelkõige linnas tegutsenud eesti ettevõtete kohta. Kasutan seda materjali siin artiklis vaid põgusalt, kuna see väärib omaette põhjalikku käsitlust.

Olen 20 aasta jooksul korduvalt väliseesti peredes lühemat või pikemat aega külas olnud ning osalenud üritustel nii Rootsis, Ameerikas, Kanadas kui Austraalias. Seega olen teinud tähelepanekuid ka osaleva vaatluse korras, mille alusel kirjeldan siin lühidalt eestipärase toidu positsiooni tänapäeva väliseesti kogukonnas (pagulaste ja nende järeltulijate pered, kuhu on lisandunud ka uusi väljarändajaid).

Käesolevas artiklis on kõrvale jäetud publitseeritud mälestusteraamatud, kus leidub toitu ja maitseid puudutavaid episoode. Samuti vajaksid veel analüüsimist väliseesti kokaraamatud ning algselt Rootsis ja hiljem Kanadas välja antud kodu- ja käsitööajakiri Triinu, kus oli igas numbris nõuandeid ja retsepte. 


\section{Esimesed maitsemuljed võõrsil}

Eestist lahkuti peamiselt Teise maailmasõja viimasel aastal. Inimesed olid üldiselt sõjaaegsete oludega harjunud ja igapäevaelu selle järgi kohandanud. „Uurimustes, mis käsitlevad sõjaaegset ja -järgset toitumist, täheldatakse mälestuste keskendumist majanduslikule kitsikusele, kusjuures tegemist ei tarvitsenud olla tegeliku näljaga. Need mälestused muudab kibedaks see, et harjumuspärasega võrreldes oli toitumisstruktuur täiesti muutunud: ei olnud suhkrut, kohvi ega mingeid delikatesse“. (Jürgenson 2011: 125)

Sü̈̈a oli keskpäraselt sel ajal, olid juba toidukaardid. Pean ütlema, et siiski oleks tahtnud rohkem sü̈̈a ja tundus, et liha, võid ja rasvaineid oli liiga vähe mä̈̈ratud toidukaartide süsteemi järele. Olime ju olnud oma kodumaal suured lihasöödikud ja senini polnud veel tundnud toidupuudust. (KV 1015: 1/49)

Kaks esimest sihtkohta, kuhu põgenikud maabusid, olid Rootsi ja Saksamaa. Seal olid mitmed toiduained talongide peal, kuigi Rootsis oli olukord kergem, sest riik ei olnud sõjas. Põgenemise järel sattusid inimesed aga täiesti uude olukorda. Toidu raskele kättesaadavusele ja sõjaajast tingitud piiratud valikule lisandus peagi uus probleem: maitsed ja valmistamisviisid olid võõrad ja harjumatud. Rootsi oli geograafiliselt küllalt lähedal ja Saksamaa kultuuriruumiliselt üsna tuttav, sest tänu baltisakslastele olid eestlased saksapärasega varemgi kokku puutunud. Ometi tuleb arvestada, et 20. sajandi esimesel poolel kuni sõjani olid Eesti inimesed üsna paiksed, nii et võõraste toitudega nad eriti kokku ei puutunud.

\section{Rootsi}

Rootsi põgenemine algas tasapisi juba 1943. aasta kevadel, kuid massiliseks muutus see siiski alates 1944. aasta augustist, kestes kuni sama aasta oktoobrini (Raag 2009: 58-59). Pärast inimeste vastuvõtmist Gotlandil või Rootsi skäärides paigutati nad kiiresti karantiinlaagritesse, kust juba mõne kuu pärast hakati põgenikke järk-järgult Rootsi tsiviilellu lubama. Seetõttu jäi seal n-ö rootslaste korraldatud ühistoitlustuse periood üsna lühikeseks ja peagi asusid põgenikud ise endale toitu valmistama.

Rootsi põgenenud inimestel on üks ühine kogemus, mis muu põgenemisloo sees enamasti mainimist leiab - esimene kokkupuude sealse toiduga. Eestlaste arvates oli Rootsi toidukultuur väga veider, sest Eestis soolase toiduna juurdunud road olid suhkruga magustatud. Neid imestust tekitanud episoode oli lugudes küllaltki palju.

Toit muidu väga hea, ainult ainukene viga, mis meile eestlastele tundus, oli väga magus. Eriti on siis pruunid oad, mis pakutakse praetud peekoniga ja oad on siirupiga magusaks tehtud. Nii, et see eestlase suus, kes seda esimest korda maitseb, ei passi mitte sugugi. Ja kastmed. Lihakastmes ka suhkur, igal pool palju suhkurt, saial palju suhkrut. (EA 263: 1/153) 
Ja lotad seal keetsid meile sööki, kuni meie oma poisid seal leidsid, et toidukraam oli seal kõik söödav ja hea, aga lotade söögikeetmise kombed ei vastanud kuidagimoodi meie maitsele, kõik mida tehti, oli suhkruga pooleks. Heeringad, suured heeringad tehti, sinna kallati kulbiga peale seda magusat kastet, suured mustad rosinad sees. Söö heeringat, kuidas tahad. (EA 264: 1/131)

Suhkur polnud probleemiks ainult heeringa ja kastme puhul, vaid seda kasutati põgenike hinnangul Rootsis liiga rohkelt ka muude toitude valmistamisel. Näiteks leib nägi küll eestipäraselt tume välja, kuid maitses magusalt ja oli tekstuurilt hoopis teistsugune. Eestlased ei harjunud sealse leivaga ja küpsetasid seda ise kodus, samuti tekkisid suurematesse keskustesse eestlastest pagarid, kes valmistasid juuretisega rukkileiba.

Rootsis aga anti seda leiba, kus on nii palju suhkurt sees ja nad on pehmed, nii et vajutad leiva kokku, siis on täitsa koos ja kui võtad käe ära, siis tõuseb üles. Nii, et niuksed konsistentsid ja maitsed. Rukkileiba Rootsis ei tuntud üldse, kui meie tulime. Sellepärast, et kõik see tume leib on värvitud leib, tähendab nisust tehtud, aga värvitakse karamellivärviga pruuniks ja siis näeb välja nagu rukkileib. Esimesed leivavabrikud asutasid eestlased Stockholmis. (EA 263: $1 / 51$ )

Rootsi leib oli magus ja tihti nätske, maitseainetega maitsestatud (aniis, pomerants), võis küll olla hea, aga mitte leiva eest. Vanaema küpsetas eesti rukkileiba ise, nii nagu seda tehti paljudes eesti peredes. Tekkisid ka ruttu eesti pagarid suurematesse linnadesse ja jagasime oma leivakultuuri rootslastelegi. (KV 1005: 21/319)

Toidukultuur väljendub selles, milliseid roogi me omaseks peame ja milliseid võõrastame (Bardone, Kannike, Põltsam-Jürjo, Plath 2016: 8). Oli ka neid toitusid, mis olid eestlastele nii võõrad, et nende söömine ei tulnud kõne allagi. Üks tüüpiline näide on rootslaste eriline pidusöök hapukala.

Me siis vaatasime, et saada soolast, siis ostsime, see oli sügis, ostsime, vaatasime, et karbikilu, kui me selle lahti tegime, siis see haises nii kohutavalt. Siis me arvasime, et on halvaks läinud, mü̈̈di seda pagulastele. Panime selle kusagile puuriida vahele, siis tuli üks laagri perenaine sealt mööda ja ütles: "Mis asi see seal on?" Me ütlesime et halvaks läinud see asi. Ta ütles, et see on delikatess rootslastel. Nii nimetatud syrströmming - hapu kala. (EA 263: 1/30)

Omamoodi probleemiks kujunes see, et mitmed eestlastele harjumuspärased toidukaubad puudusid Rootsi toidutraditsioonis täiesti. Nii ei tuntud seal ei kohupiima, hapukapsast ega ka verivorsti. Kui viimane oli ka Eestis hooajatoit, siis kahte esimest oli enne põgenemist tarbitud üsna igapäevaselt ja nendest tunti vähemalt esialgu suurt puudust.

Aga siis oli see, kohupiima üldse Rootsi ei tundnud, see toodi ka sisse esimest korda, eesti ärid seal kaubahallis hakkasid ka tegema ise kodus ja siis müüdi seal lahtiselt, aga nüüd on see juba suur produkt Rootsis üldiselt läinud sisse. Täitsa tundmatud asjad. Hapukapsast rääkimata. Hapukapsast oli müüa seal turuhallis, tähendab ainult üks koht Stockholmis ja mujal vaevalt. Nii et seepärast oli haruldus, kui seda sai ja seda ei saanud ka aasta läbi. (EA 263: $1 / 51)$ 
Nagu näha, sattusid Eesti põgenikud teisel pool Läänemerd võõra toiduga seoses kohanemisraskustesse, kuigi kodule oldi üsna lähedal. Viimasest tsitaadist jääb mulje, nagu oleks eestlased toonud rootslastele korraliku toidukultuuri ning tutvustanud neile maitsvat ja tervislikku toitu. Mitmed inimesed mainisid ka, et tänapäeval ei ole Rootsi söögid enam nii magusad, kuna nad on aru saanud suhkru kahjulikkusest.

Lõpuks, see võttis veel mõni aasta, enne kui Rootsi ühiskond hakkas aru saama, et see ei ole hea. See ei ole tervisele hea nii palju magusat teha. See asi on täielikult ära kadunud. Seda enam ei ole... Et magusat tarvitatakse magustoidu jaoks jah, ja magusa saia ja kookide jaoks. See on õnneks ära kadunud jah. (EA 264: 1/115)

Rootsi jäi paljudele põgenikele lõplikuks asukohamaaks ja paratamatult kohanesid nad aastakümnete jooksul sealsete roogadega, sest maitsed muutusid harjumuspäraseks.

\section{Saksamaa}

Kui Rootsi põgenenute mälestustes on esimestest maitseelamustest üsna palju juttu, siis Saksamaale läinud inimeste puhul see teema praktiliselt puudub. Üheks põhjuseks on kindlasti see, et eesti toit on üsna tugevalt saksa köögist mõjutatud ja seetõttu on maitsed sarnased. Teiseks oli vaja sõjas oleval Saksamaal esialgu palju rohkem tegeleda ellujäämise ja tulevikuga. Toidu maitse ei olnud seega kõige tähtsam.

Meie toit oli ääretult vilets: kaks tükki leiba, tass „Ersatz" kohvi ja väike tükk marmelaadi päevas. Lõunaks sai natuke mingit kapsasuppi ja muud ei midagi. Olime pidevalt näljas. (KV 1010: 3/41)

Überlingenis me saime sakslastega samasuguse toidukaardi, mis oli elamiseks vähe, aga hinge siiski sees hoidis. Õnneks oli meil Eestist kaasavõetud mõnikümmend pakki eesti paberosse, siis sai nende eest vahetada talumeeste käest puu- ja juurvilja ja vahel ka tükikese suitsusinki. See aitas meid seda viimast sõja-aastat üle elada. (KV 1010: 13/285)

Meil kellelgi ei olnud palju süüa. Leiba vist saime nii palju, et meile emaga jätkus, ei mäleta, et oleks just pidanud leivaga kokku hoidma. Aga palju leiva kõrvale ei olnud saada. Meeles on kaks toitu, mis näisid olevat saadaval. Esimene nendest oli heeringa salat, tehtud keedetud kartulite ja peediga. Pealt vaadates võis isegi rosoljeks pidada, aga maitse just sama ei olnud. Teine pala, mis oli saadaval, nägi välja kui sült - ühesõnaga, kui üks liha-tallerdis. Seda sõime ja ostsime nii kaua kui avastasime, mis sorti lihaga oli tegemist; nimelt oli see teo liha. Tänapäeval saab tigusid tellitud peenes restoranis, peene nime all, aga 1944 pool näljas nagu me olime, läks isu ära, kui teadsime millest „sült“ koosnes. (KV 1013: 4/148-149)

Saksamaale jõudnud põgenikud elasid esimese kevadtalve kuni 1945. aasta maijuunini üle omal käel, otsides nii tööd, elukohta kui söögivõimalusi mitmest piirkonnast. Mõnedel põgenikel õnnestus Eestist kaasa võtta ka soolakala, -pekki või rasva, mis oli kindlasti esimesel talvel abiks. Aga kodusel toidul oli veel teinegi tähendus - see oli kodumaa toit, mis tekitas otsese seose nii kodu kui kodumaaga. 


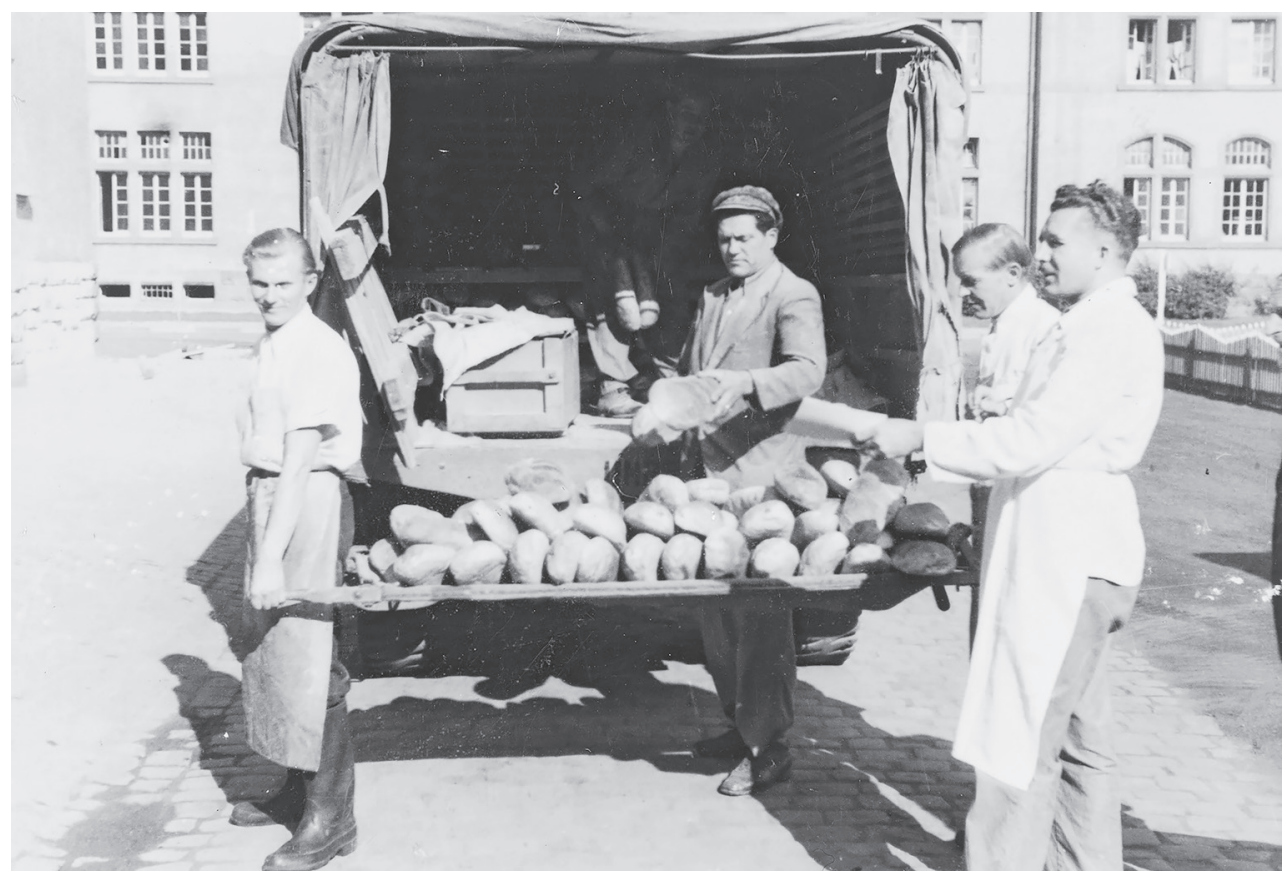

Foto 2. Leivajagamine Wiesbadeni põgenikelaagris 1946. aastal. Oskar Kuusik (valge põllega) vastu võtmas laagri päevast leivanormi.

ERM Fk 2910:354

Arvan, et see oli vist Brandenburgi lähedases laagris, kus sõime viimased kuivatatud soolasilgud, mis vanaema oli Kassarist kaasa andnud. See oli nagu matuseõhtu - nagu viimane side kodumaaga oli nü̈̈d katkenud. (KV 1016: 3/252)

Laagrite moodustamine algas sõja lõpu järel ja peagi elas enamik Eesti põgenikest DP-laagrites. ${ }^{1}$ Kuni 1947. aasta keskpaigani puudus kindel kord ja jaotus, milline riik või organisatsioon konkreetseid laagreid haldab ja kust lähevad võimupiirid (Kumer-Haukanõmm 2009: 20). See mõjutas otseselt inimeste toitlustamist ja toidu kvaliteeti. Samuti olid laagrid erinevad: mõnel pool toimus toitlustamine ühisköögist ja enamasti olid inimesed siis rahuolematud nii toidu hulga kui kvaliteediga. Teistes jagati aga toiduained inimestele välja ja kõik said endale ise vastavalt oma harjumustele ja maitsele süüa teha.

Oxfordi [DP-laager Saksamaal] oli koondatud suurel hulgal põgenikke, eestlasi ja muulasi. Söök oli ühiselt keedetud, sest barakkides polnud keedu võimalusi ega põgenikel raha toidu ostmiseks. Liitlased varustasid meid toiduga. Iga rahvusgrupi köök oli eraldi. Toit oli vilets ja väheldane. Kasvavatel noortel oli kõht tihti tühi. /.../ Naised käisid metsas seeni korjamas. Kord oli meil kodus söögiks suur pannitäis seenekastet kartulitega. Vahest tehti toitu oma toas laenatud priimusel. See seenekaste oli kõige maitsvam toit, mis kunagi olin saanud ja

[1] DP - displaced persons 


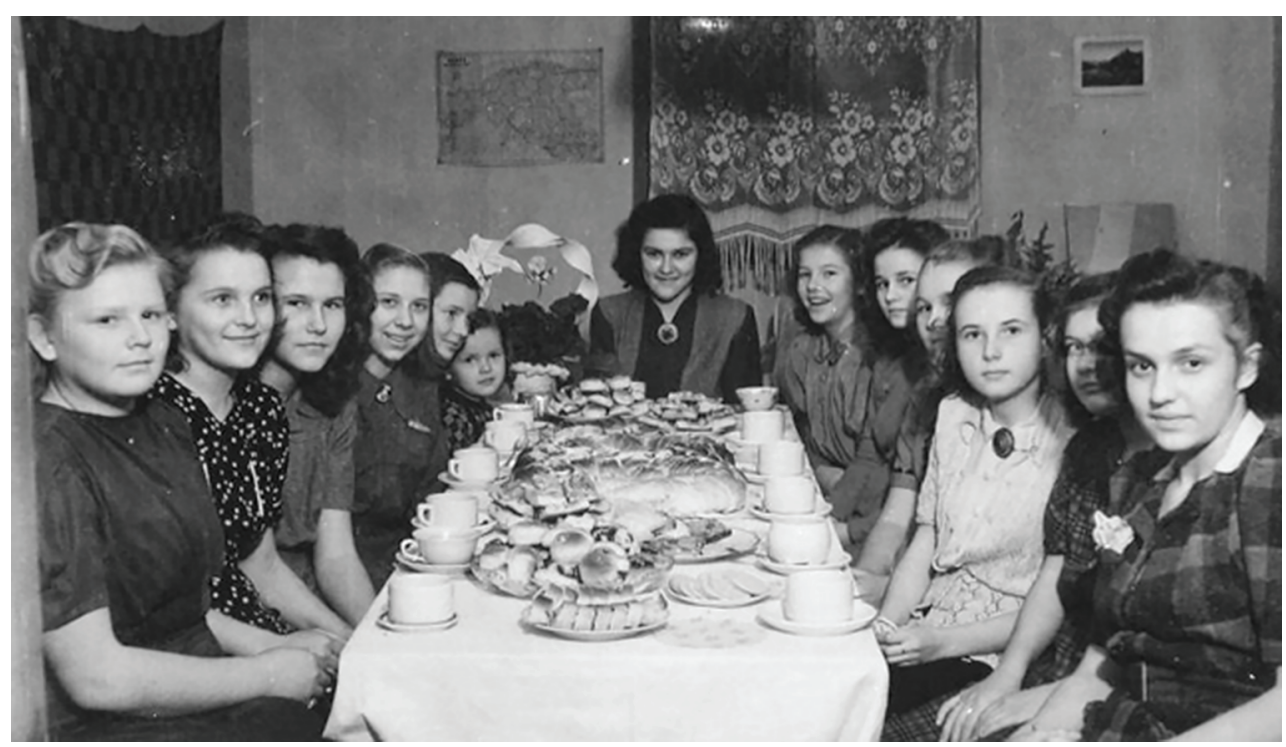

Foto 3. Lia Nõukase 16. sünnipäeva kohvilaud kringli ja pirukatega Löwensteini [?] põgenikelaagris 1948. aastal.

ERM Fk 2910:461

ma oleksin võinud terve pannitäie üksi ära sü̈̈a, aga pannitäis jagati neljaks ja mul jäi kolmneljandikku kõhtu tühjaks. (KV 1090: 1/40-41)

Meie laagris [Haunstetten] anti toiduained inimestele välja ja igaüks pidi ise omale keetma, siin laagri poolt üldist toidukeetmist polnud. Ja see oli ka parem. Jäid ära need lahja supi jutud. Igaüks keedab omale ise nii nagu ta heaks arvab. Üldiselt olime väga rahul oma eluga, muidugi niisuguseid aineid, nagu köögivilja ja aedvilja tuli juurde muretseda, samuti rukkileiba. Laagris anti ainult saia. (KV 1087: 1/96)

Laagrites jagati inimestele ka Ameerikast saadetud abipakke, samuti saadi osa sõjaväe toiduvarudest. See oli reeglina esimene kokkupuude ameerikalike toiduainetega, mis muutusid hiljem Ameerikasse väljarändajaile elu lahutamatuks osaks.

Suur erinevus oli aga laagris antava konservtoidu ja me harjunud oma vahel. Kuidagi polnud võimalik neist midagi eestipärast valmistada. Küllap perenaised tegid mis suutsid, kuna aga mina keetmisest palju ei hoolinud, leppisin antud toiduainetega. (KV 1009: 10/163)

Laagris elamine oli prii, ei pidanud toa ega söögi eest maksma. Köögis sai küll palju nalja, toit tuli kas purgis, kuivatatud või pulbrina ja leiva asemel anti valget pehmet saia. Küll oli tore sü̈̈a, kuigi igakord ei teadnud, mida sõime. Saime purgi sees sinepivärvi paksu määret, polnud varem niisugust asja näinud. Laagrirahvas kutsus seda "Ahvi Higiks". Proovisin saiaga sü̈̈a, jäi suulae külge kinni, raputasime suhkrut peale. Alles aastaid hiljem Ameerikas sain teada, maapähkli või tuleb süüa röstitud saial moosiga, siis maitseb hea. (KV 1012: 7/103)

Otsuse Saksamaalt lahkuda langetas enamik eestlasi 1946. aasta lõpul ja 1947. aasta algul (Kool 1999: 677). Mindi Inglismaale, Austraaliasse, Ameerika Ühendriikidesse ja Kanadasse. Rootsist edasirändamist mõjutas Balti sõdurite väljaandmine Nõu- 
kogude Liidule 1946. aastal ja 1948. aastal puhkenud Berliini kriis. Kardeti uue sõja puhkemist Euroopas ja taheti Nõukogude Liidust võimalikult kaugele pääseda. Rootsist rännati peamiselt Kanadasse, kuid väiksemal määral saadi immigratsiooniõigus ka Ameerika Ühendriikidesse. See tähendas põgenike jaoks taas kohtumist uue maa ja kultuuriga, sh toidukultuuriga. Kuna väljarände sihtpunktidesse jäädi elama alaliselt, algas tasapisi kohanemine uute toitude ja maitsetega.

\section{Inglismaa}

1946. aasta sügisel algas esimene aktsioon „Balti luiged“, mille sihiks oli eelkõige vallaliste naiste tööle värbamine haiglatesse. Sellele järgnes kohe „Hõissa läände“, millega pääsesid Inglismaale tööle nii mehed kui ka naised (eelkõige vallalised) (Kumer-Haukanõmm 2009: 30-32). Inglismaale väljarännanute puhul on oluline tähele panna, et enamik neist olid üksikud noored inimesed. Paljud mehed nende hulgast olid teeninud Saksa armees ja läbi elanud vangilaagri Saksamaal ja Belgias.

Alguses, Inglismaale tulime, Saksamaal oli poolnäljas oldud ja siis no sõid inglise toitu kõik, mis anti ja mis oli saada. Ja nü̈̈d, kui oma peal hakkasid elama, siis vaatasid ka, et kus oli saadud välismaa toitusid, vorstisid ja ostsid neid ja tegid oma käe peal valmis. (EA 262: 1/235)

Kui me linna läksime, siis me ei tea, mis me oleks ära ostnud sealt, kõike oli nii palju saada. Meil olid kõhud tühjad, mida me kõige rohkem ostsime, olid õunad, jah... siis muidugi fish ja chipsi, seda sõime ka. Mitte üks portsjon korraga, ikka kaks portsjonit korraga. (EA 262: 1/49)

Kui esimene nälg sai kustutatud, tekkis peagi igatsus harjumuspärase toidu järele. Edgar Saar tõdeb Inglismaa eestlaste mälestustele tuginedes samuti, et inglise toidud erinesid eesti omadest (Saar 2000).

No inglaste toit oli meile võõras teatud suhtes. No eriti nagu siin ei tuntud rukkileiba, siin ei tuntud üldsegi. /.../ Nii et inglased ise väga vähe variante oli, mida nemad kasutasivad. Palju asju mida... näiteks meil oli ju hapukapsas, mida me tahtsime. Inglasele hapukapsast vägisi peale, mõtlesime, et hakkab surema, kes sedasi teeb. Ja hapupiima oli näiteks ja me töötasime villalaos, kui kuum suvi oli, siis ma sihilikult lasin piima hapuks. Ma mäletan juba Eestis, et soe hapupiim oli hästi karastav kuumaga juua ja kui inglane nägi, et ma hapupiima joon siis tahtsid kohe ambulantsi kutsuda. Ma ütlesin, et ei ole midagi, et see on väga hea ja jättis mu siis rahule. Käis vaatas nurga tagant, et kunas ma surema hakkan. (EA 262: 1/83)

Toit toit, vat toit on erinev. Inglane ei söö haput kapsast. Inglane sööb... rukkileiba ei ole siit saada. /.../ Inglased, nemad söövad kõik erinevalt. Nemad söövad beef-i, loomaliha, lehmaliha ja see on pooltoores. See on nisukene liharibad lõigatakse. Siin... nii üks liharaas ja teine pannakse peale ja vastavalt küpsetatakse. Nüüd mõlemad päälmised pooled küpsevad ära, keskmine pool peab pooltoores olema ja söövad, aga söövad isuga ja ma seda ei söö üldse. Ma ei ole seda proovindki mitte, see ei kõlba. (EA 262: 1/100)

Kui Euroopast pärit sisserändajad hakkasid avama oma väikseid toiduärisid, sobis seal pakutav kaup paljuski ka eestlastele. Kui peres oli eestlasest naine, valmistati kodus eestipäraseid roogi, eriti pühadeks. 
Lõpuks hakkas Inglismaale tulema ka välismaa toitu. Nii, kui sai heeringat osta ja kurke juba osta ja poolakad tegid siin, mõned poolakad avasid kahe-kolme poolaka peale, avasid toiduainete äri, hüüti delicatessen äri, delikatessi äri. Seal oli siuke, Poolast toodi sinna toitu. Hapukurke ja heeringat ja igasugusi Poola moosisid ja, nii et sai neid toitusid osta. (EA 262: $1 / 262)$

Jah, sest me ikkagi, meie menüüd on olnud ikkagi väga need, mis on olnud lapsest pääle. Muidugi Inglise toitusid me sööme ka ja, aga kuidagi ikkagi meie jõulutoidud ja sült ja vorstid ja hapukapsad ja need ikka koguaeg ja üldse pühadetoidud ja pühade ja tähtpäevade lauad on ikka kaetud rohkem eestipäraste toitudega. (EA 262:1/161)

\section{Kanada ja Ameerika Ühendriigid}

Suur muudatus tuli Euroopasse jõudnute ellu, kes ootasid kolmandatesse riikidesse ümberasumist, pärast 1948. aasta suvel Ameerika Ühendriikide Kongressis vastu võetud DP-de seadust. Eestlasi asus USAsse umbes 10000 (Kumer-Haukanõmm 2009: 43-45). Kanadasse hakkasid sisserändajad jõudma samuti 1948. aastal pärast immigratsiooniseaduste liberaliseerumist (Kumer-Haukanõmm 2009: 41). Karl Auna andmetel asus nii Rootsist kui Saksamaalt Kanadasse ümber umbes 13000 eestlast (Aun 1985: 14-27).

Üldiselt pidasid eestlased nii Kanada kui Ameerika sööke ebatervislikuks ja mitte eriti maitsvaks. Tagasivaatavalt suhtutakse Ameerikas 1950. aastatel kogetud kulinaarsetesse elamustesse üsna põlglikult. Pigem peetakse ameeriklaste maitset üsna lihtsaks. Oli ka olukordi, kus mõnda toiduainet tarvitati eestlaste arvates valesti.

Kõike oli külluses, kuid valikut ja head maitset leidus vähe. Toit oli väga ebatervislik. Rukkija täisteraleiba näiteks üldse ei tuntud. Paar saadaolevat juustusorti nägid välja nagu seep ega maitsenud. Vorstid olid väga soolased ja rasvased. Puu- ja juurviljast ei peetud suurt lugu. Sedagi sai peamiselt konserveeritult, surnuks keedetult. (KV 1010: 2/27)

Kui me siia tulime 1950. aastal ja olime laevaga tulnud New Yorki ja siis tulime rongiga Torontosse, et siis tellisime võileibu rongis. Ja me olime väga šokeeritud kui me nägime seda leiba esimest korda. See oli nagu valge vaht ja me mõtlesime, et nisuke leib on siin. (EA 283: 3/368)

Tema [majaperemees, kelle juures oldi korteris] võid ei söönud, sõi margariini (taimevõid), mis palju odavam. Olime seni omaette elades ikka võid või teinekord rasva leivale määrinud. Margariiniga polnud harjunud. Marta ikka katsus sü̈̈a, kuid mulle margariin ei maitsenud. Niisiis otsustasime ise endale võid osta. Aga kuidas sööd võid nii, et vanamees ei näe. Korraga on laua ääres söomine. Hommikul abikaasa pani siis ka oma või lauale ja istusime lauda sööma. Vanamees luges alati enne söömist palve. Mina hakkasin siis pääle palve kohvi jooma ja panin leivale võid pääle. Vanamees silmitses, silmitses, lõi rusikaga vastu lauda, ütles: „Mis see siis tähendab". Kas margariin ei kõlba süüa. Tema söövat eluaeg margariini. Tähendasime, et meie küll ei söö. Tähendab teie pole nälga siis veel tundnud. /...। Sellest margariini loost tekkis esimene arusaamatus meie vahel. (KV 1015: 1/180-181) 


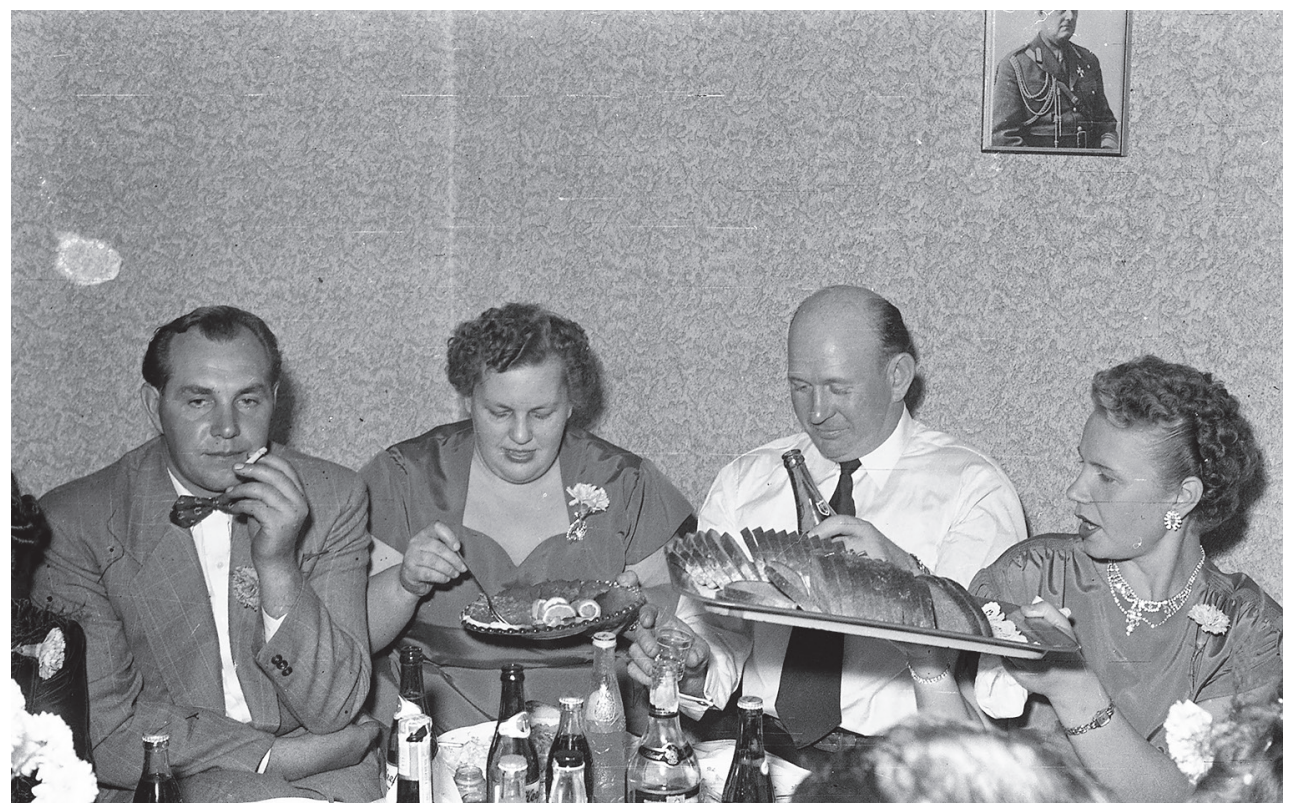

Foto 4. Sünnipäevapidu Torontos 1950. aastatel. Foto: J. Säägi.

Väliseesti Muuseumi kogu

Ameerika ja Kanada kujunesid paljudele põgenikele lõplikuks asukohamaaks. Üha enam kohaneti kohaliku toiduga, kuid alles jäi igatsus rukkileiva järele ja pidupäevadeks valmistati ikka eesti toitu. Minu esimene kokkupuude rukkileiva küpsetamisega kodus pärineb samuti Ameerikast, kui olin 2001. aastal mõned kuud Californias. Küpsetasime koos 90 -aastase proua Renatega leiba, mida kogu tema perekond kuni lapselapselasteni pikisilmi ootas. Eestis ei olnud sel ajal veel koduleiva küpsetamine nii moes, sest poes tundus olevat küllalt suur valik.

Toit oli osalt eestipärane, osalt õppisime ka ameerikapäraseid toite tarvitama, nagu igahommikune apelsinimahla joomine, kalkunisöomine jne. Ei meeldinud siinne pehme sai, mis ainult röstituna kõlbas. Eestipärasest mustast leivast oli puudus. Ka ameerika koogid ja maiustused ei meeldi, need on liiga magusad. Seepärast küpsetan ise, ka magushaput leiba. (KV 1010: 10/220)

Ja muidugi, mis kõige ebameeldivam, oli see, et me ei saanud kusagilt rukkileiba. Me saime seda pehmet saia, mida me kutsusime švammsai. Ja ma mäletan, kui me Kansases elasime, ema ütles niimoodi, et enne surma ma tahan saada veel tüki heeringat ja musta leiba. Ja kui Chicagosse tulime, muidugi, et siin on nii palju etnilisi gruppe, et siin on kõike saada. Heeringat, musta leiba, kilu või mis sa iganes soovid. (EA 277: 1/149)

Ameerikas ja Kanadas omandas erilise positsiooni kringel. Enamasti on see seal sünnipäevalaua lahutamatu osa ja seda pakutakse alati kohvi kõrvale Eesti Maja jt organisatsioonide üritustel. Kui kringlit juhtub üle jääma, võib ikka märgata, kuidas keegi mässib kringlitüki salvrätikusse ja poetab taskusse, et viia see pereliikmetele või jätta endale järgmise päeva kohvikõrvaseks. 


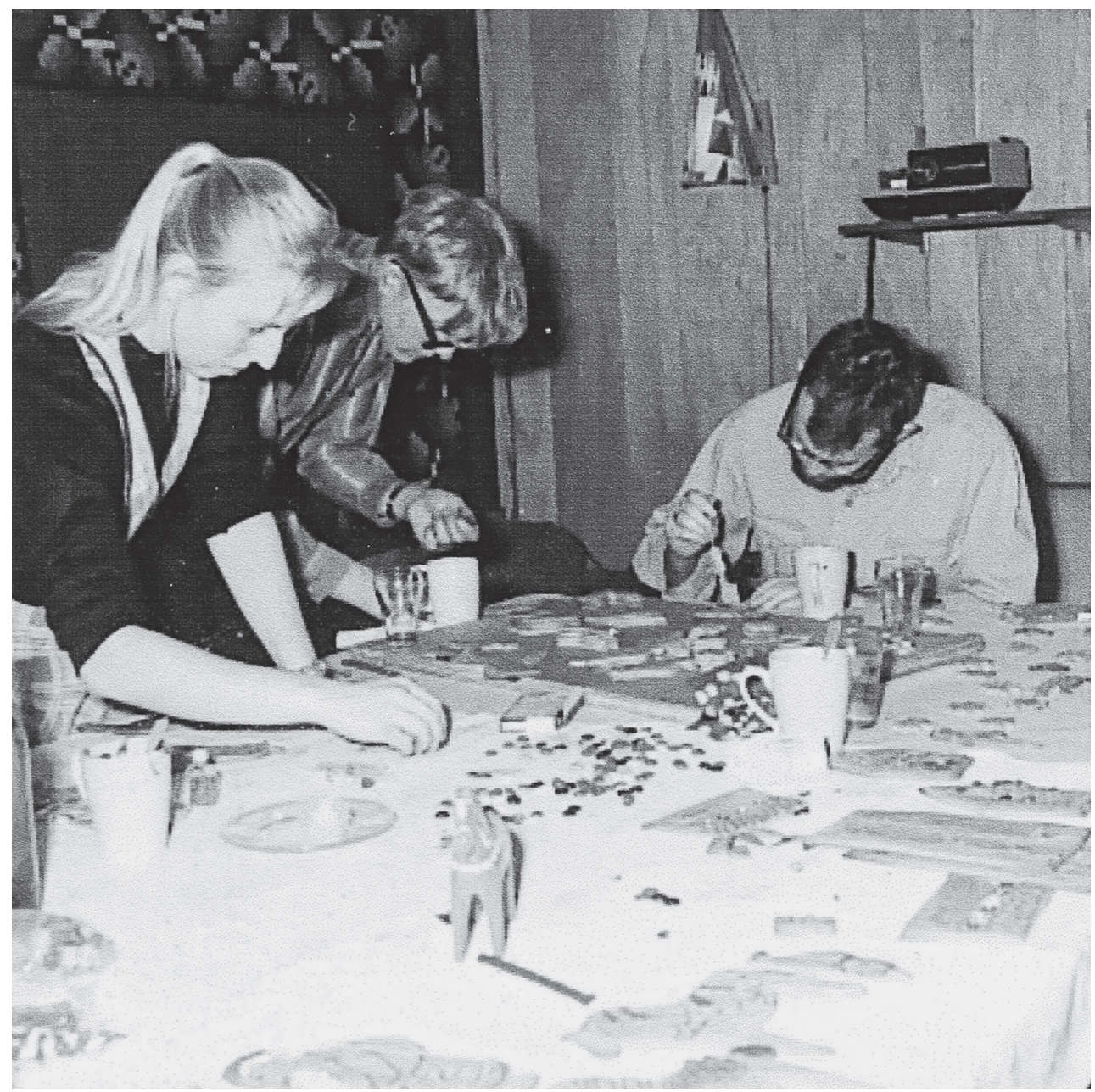

Foto 5. Perekond Loo Kanadas Vancouveris piparkooke valmistamas. 1980. aastad.

ERM Fk 2910:642

Ma ei mäleta, kuidas algas see kringli traditsioon, alul väheselt, kuid järjest suureneva perekonna tõttu, abiellumised, perekondade juurdekasvud, perekondlikud kokkutulekud pühadeks ja muud tähtpäevad, meie köögist läks välja 40-50 kringli ümber aastas. (KV 1006: 5/89)

Täiesti erandlikus olukorras olid Toronto ja selle ümbruskonna eestlased, kuna seal asutasid põgenikud 1950. aastate alguses nii pagari- ja kondiitriärisid (Viking, Rooneem, Krabi, Amjärv) kui ka lihatööstusi (Poko, Central Meat). Paljud neist töötasid mitukümmend aastat, kuid hiljemalt 1980. aastatel müüdi need uutele mitteeestlastest omanikele. 2014. aastal valmis Toronto eesti toiduäridest film „Toidutoojad“, mis tugineb nii omanike, nende pereliikmete kui ka klientide mälestustele (Noorhani, Pitsi, Reinvelt 2014). Linnas oli piisavalt palju eestlasi ja teiste Balti riikide esindajaid, kes nende toodangut ostsid. Toronto oli toidu kättesaadavuse tõttu atraktiivne ka nendele eestlastele, kes elasid mujal selle läheduses. Mitmes 
intervjuus mainitakse, et kui satuti Torontosse külla sõitma, siis kindlasti osteti kaasa rukki- või peenleiba, mida kohalikud eesti pagarid valmistasid. See oli teadatuntud fakt, et Torontost sai eesti leiba ja muud eesti toitu. Rooneeme pagariäri üks omanikke Aino Rooneem meenutas:

Ja nü̈̈d kui inimesed tulid siis Ameerikast mingisugusel põhjusel, kas külla oma sugulasele või tähendab eestlased eksole ja ka lätlased. Siis nad võtsid alati palju seda peenleiba kaasa. Ja see auto tagune see, mis ta on, see pagasnik, see oli siis leibu täis. No ja piiri peal nad ütlevad, et: "Mis teil seal on? Leivad? Te sõidate Kanadast Ameerikasse, kas meil siis leiba ei ole?" Ja nad ei uskund, nad lõikasid leivad pikku pidi katki. Nad mõtlesid, et on midagi sisse pandud eksole, seal on ju väga hea, midagi peita, ükskõik mis asja. /.../ No siis nad pärast enam ei lõiganud. Nad juba teadsid, tegid selle lahti: "Ahh, Estonian bread again!" (EA 283: 3/269)

\section{Austraalia}

1951. aastaks oli IRO abiga Austraaliasse ümber paigutatud 5958 eestlast (Madise 1966: 183). „Austraaliaga esmakohanemise hulka kuulus toidufolkloor, mis omakorda hakkas suurte sisserändavate erikultuuriliste rahvusrühmadega koos muutuma. Alguses oli siiski tegemist mitmete eelarvamustega, kusjuures immigrandid uskusid vice versa, et uue asukohamaa elanikel on veidrad tavad ja hullud söömiskombed." (Kõiva 2012: 132)

Meie rahvas sõi igapäevasel laual teiseti kui kohalikud. I... / Kartuliga oldi alati hoopis kokkuhoidlikumad kui meie rahval tavaks oli. Austraallased arvestasid ainult pool kartulit inimese kohta ja peremees sai ainult terve kartuli. Kord oli meie köögis naabri tüdruk, kes ei jõudnud ära imestada kui nägi mind keedetud kartulaid koorimas ning koos sibulaga praadimas. Ta polnud kunagi näinud et kartulaid jääb üle nii et neid ka "soendada" saab. Küsimusele, "kas sinu emal siis ei jää kunagi kartulaid üle lõunasöögist, arvas tüdruk, et seda pole veel juhtunud, kui ka isast peaks pool kartulit üle jääma siis tema palub emalt selle alati endale. /.../ Üldse kogesin, et inglise köögis puudus magushapu maitse. Kõik seal oli kas ülimagus või siis soolaga tehtud. (KV 1014: 1/17)

Nadia Postiglione (2010) on analüüsinud, kuidas Briti ja Itaalia immigrandid Austraalia laagrites ja sealses ühiskonnas toiduga kohanesid. Artiklis tuuakse esile, et üldiselt oli kogemus võõristav ja diskrimineeriv. Näiteks itaallased keeldusid laagritoidust, kuna see oli võõra maitsega, aga ka seetõttu, et seda valmistasid muust rahvusest laagrielanikud. See näitab, et samadest koostisosadest süüa tehes on tulemus sõltuvalt toidu tegija rahvusest erinev. Samasugustest kogemustest on rääkinud ka Austraalia eestlased.

Kohaliku rahva üks harilikke toite Black Pudding oli meil jõululaual ainult ühel korral. Selles polnud eestipärasele verivorstile maitset andvaid tange. Adelaide'is hakkas viiekümnendail aastail üks poola ärimees turustama meiepäraseid tangu-verivorste. Tema vorstides oli aga mingi meile mitte meelepärane maitse, mistõttu tarvitati tema kaupa ainult "häda korral". (KV 1008: 6/206)

Kui keegi meie inimestest juhtus Melbourne sõitma, siis anti kaasa "nimekiri“. Melbournes oli nimelt üks pood, kust sai rukkileiba ja Krakovi vorsti. Need olid pidupäevad. Austraalia 
vorstid olid tol ajal rasvased ja paha maistega. Leib oli ka selline, et pool pätsi sai lõigata, teine pool lagunes lihtsalt noa all ära. (KV 1014: 3/52)

Kohaliku rahva maitsepärased vorstid olid meile praktiliselt mittesöödavad nende imelikkude maitseainete tõttu. Väga vähestele eestlastele meeldis ka kohaliku töölise lõunatoit või koguni siinmaa "rahoustoit" pie (pirukas guljašštäidisega). Kohaliku rahva leib (sai) oli maitsetu kuni umbes aastani 1953, siis hakkas üks firma (Sanitarium) turustama sepikut ja kui asutati esimesed selvekauplused, ilmus riiuleile ka musta leiba. Meie pere sõi aga musta leiba juba alates umbes aastast 1952, kui avastasime, et kanasööda rukkijahust sai ema teha "head eesti leiba"! Ka tundus kohalik või meile liialt soolane, mu ema pesi sellest alati palju soola välja, enne kui see meie lauale jõudis. (KV 1008: 6/205)

Postiglione rõhutab ühte konkreetset toiduainet, mis leidis kõigis tollastes immigrantide lugudes eraldi käsitlemist. Nimelt nimetati lambaliha ja rasva korduvalt stressiallikana, millega varase kohanemise staadiumis hädas oldi (2010: 09.9). Ka eestlased ei meenuta esimesi lambaliha kogemusi just positiivsena, sest see, mis laagrites pakuti, oli pigem rasvane vänge maitsega vana lamba liha, mille mekki oli hiljem raske unustada. Samuti oli probleemiks lihavaliku ühekülgsus - domineeris lambaliha.

Austraalia toit mõjutas meie toiduharjumusi vähe ja Austraalias väga maitsvat kevadist talleliha (spring lamb) vältis enamus eestlasi. Mälestus Bathursti laagri söögisaalis külmana serveeritud lambalihast (mutton) ei tahtnud kergelt ununeda. (KV 1014: 5/97)

Mulle toodi hulga kapsapäid. Mida teha? Tellisin tünnid, panin teenistujad (köögitöölised) kapsaid riivima ja täitsin tünnid nii nagu seda oma lapsepõlve kodus olin näinud. Mõne nädala pärast olid kapsad hapud ja mulgi kapsad maitsesid kõigile. Mulgi kapsastega käib kaasas sealiha, aga mulle toodi enamuses ainult lambaliha. Rääkisin lihatoojaga, et kas ei saaks osa lambaliha vahetada sealihaga. Andsin mõne konservi ja kuivatatud puuvilja, mis mul üle jäi. /.../ varsti oligi mul sealiha köögis. Valmistasin siis lõunaks seaprae hapukapsastega ja kompoti meie moodi. (KV 1012: 6/89)

\section{Eesti maitsed: isetegemine ja nostalgia}

Eestlastest põgenikud tulid ühiskonnast, kus paljusid asju, ka süüa tehti ise kodus. Sõltumata sellest, mis riiki nad lõpuks jõudsid ja kuhu kodu rajasid, pidas väljarändajate esimene põlvkond eestipärast toitu elu lahutamatuks osaks. Osalt seetõttu, et maitsed olid tuttavad ja harjumuspärased ja teisalt oli perenaistel ju sellise toidu valmistamise oskus olemas. Välismaal lähtus isetegemine tihti vajadusest, sest eestipäraseid toite müüvaid ärisid paljudes piirkondades ei olnud ja kusagilt ei saanud osta rukkileiba ja hapukapsast või ka sülti, verivorsti ning rosoljet.

Toitlustamine meie peres oli ikka vana eesti kombe kohaselt, eriti just pühade puhul. Jõulu laupäeva õhtul pärast Eesti Ev. Lutheriusu jumalateenistusel käimist (Läti kiriku hoones) sõime koos vanade, üksikuks jäänud sõpradega ikka oma tehtud verivorsti seaprae ja hapu kapsastega. Muidugi ka oma tehtud hapu rukkileib, mis on meil veel praegugi suur maiusroog ja mida siin poest osta ei saa. (KV 1233: 14/203) 
Mis oli puudu, et kui oli jõuluõhtu, siis puudus verivorst, hapukapsas, hapuleib. Sellest tundus küll täiesti puudu olevat, aga selle me klaarisime ka ise ära. Nagu ma varem olen mitmel korra nimetanud, et eestlane on niuke, niukest tüüpi inimene, et tema alla ei anna, kui mujalt ei saa, siis teeb ise ja nii siis ka meie. Verivorstid tegime ise. Hapukapsa tegime ise ja hapuleiva tegime ise. (EA 263: 2/362)

Meie pere toit oli midagi sellist nagu me Eestis olime harjunud sööma ja mida kohalikkudes poodides oli saada. Mäletan elevust kogu rahvusgrupis, kui keegi oli ühes poes avastanud, et seal müüdi magedat võid. Tollal oli see siin maal peaaegu tundmatu. /.../

Kuna tollal oli viina poodides harva, joodi viskit või džinni. Meenub pooltõsiselt avaldatud arvamus, et see olevat "kõige puhtam jook", arvatavasti seetõttu, et see oli värvitu, nagu eesti viin - ja kõik mis oli Eestis, oli kõige parem! (KV 1232: 12/137-138)

Toit ei ole mitte ainult sümbol, vaid selle juures tuleb arvestada ka valmistamise protsessi. Toiduvalmistamist on kõige parem õppida ikka konkreetse tegevuse abil (noored omandavad paljud oskused vanematelt sugulastelt nagu tavaks). Nii rõhutab Sutton (2006), et toiduvalmistamise puhul on tähenduslik osa just paljuski tegemisprotsessis, sest õigesti tehes saab ka õiged maitsed. Samas on ka tegemine järjepidevuse kandja, kui teha midagi nii nagu ema või kaugemad eelkäijad. Kuna paguluses esialgu retseptiraamatuid välja ei antud, siis toimuski teadmiste edasiandmine toiduvalmistamise kaudu.

1954. aasta Ameerika Hääles oli saatelõik pealkirjaga „Estonian woman and home in America":

Esitades järgnevalt ülevaadet eesti naisest, tema kodust ja tegevusest vabas Ameerikas, olgu kohe algul märgitud, et eesti naine ja tema kodu on jäänud ka võoras ümbruses selleks, kes ja mis nad olid armastatud kodumaal. Asunud üheksa pika aasta eest maapagulase teekonnale küll tühjade kätega, ei asunud eesti naine sellele teekonnale aga ometi mitte tühja südamega. Ta võttis endaga kaasa tulise isamaa armastuse, mis on hoidnud nii teda kui tema kodu eestilisena läbi pikkade aastate ja vahelduvate võõraste maade. (IHRC, Etti Sirg Papers)

Järgneb jutt kodu kaunistavast vöökirjast, lauanurgal seisvast Kalevipojast, sinimustvalgest lipust igas kodus ja rahvariiete hankimisest, eestluse süstimisest lastesse, osalemisest naisorganisatsioonide töös jne. Ja veel üks tsitaat saate tekstist: Oma kodu eestilisena hoidmise juures võtab eesti naine oma mehe kõrval aktiivselt osa ka meie välisvõitlusest Eesti vabaduse eest. (IHRC, Etti Sirg Papers)

Pealkiri „Eesti naine ja kodu Ameerikas" osutab, et tekstis seostatakse eestipäraste toitude söömist ja valmistamist kui olulisi markereid eestluse hoidmisel naiste ja koduga. 20. sajandi keskpaiku oli peres toiduvalmistajaks pereema. Anu Mai Kõll on analüüsinud pagulastest eesti naiste toimetulekut Rootsis ja toob välja, et võrreldes kohalike naistega käis tööl suurem osa eesti naisi (Kõll 2009). See pani naistele topeltkoormuse: esiteks palgatöö ja teiseks kodune toiduvalmistamine eestipäraste retseptide järgi. Just lapsena põgenenute lugudes mainitakse peamise toiduvalmistajana emasid või vanaemasid. Täiskasvanute lugudes on valmistaja isik naiste puhul enamasti mina-vormis, vahel ka umbisikuline, meeste puhul aga enamasti umbisikuline, väga harva mina-vormis. Toonased lapsed mainivad ka oma mälestustes, et peamiselt oli eestipäraste roogade valmistamine pühadeks ja toidutraditsioonide elushoidmine peredes ema õlul. 
Ema oli osav toidutegija ja ta keetis lihtsatest põhiainetest maitsvaid roogasid, kõik eesti traditsioonide kohaselt. Ta küpsetas ise rukkileiba ja mitmesuguseid pirukaid, tegi kohupiima jne. /.../ Tegime näiteks pelmeene. Jõuludeks tegi ema verivorsti, sülti, hapukapsaid ja pasteeti eesti moodi ja lihavõtteks pashat. (KV 1005: 19/276)

No siis kui võib-olla emal oli aega seda teha, aga siis ma pean ütlema, et tähendab need naised kes tol ajal tulid, meie vanemate generatsioonist, minu vanemad olid nii neljakümne ringis kui nad tulid ja siis nad pidid uuesti alustama eks ole. Ja siis muidugi naised käisid kõik tööl ja ma mäletan ema oli alati öösel üleval, enne kui oli jõulud või lihavõtted ja... öösel üleval, et midagi siis valmistada, mis oleks eestipärane ja et meil oleks siis pühad, eks ole. See oli kindlasti raske tal teha, aga ta tegi seda. Ja ma arvan, et võib-olla teistel oli ka samuti. (EA 283: 3/370)

Susan Holak (2014) on uurinud eri aegadel välja rännanud vene diasporaa toiduga seotud nostalgiat ja seda, millised söögid ja brändid (valmistooted) tekitavad eriti nostalgilisi tundeid. Ta toob esile, et toit, selle valmistamine ja tarbimine mängivad silmapaistvat rolli identiteedi säilitamisel ja kodu n-ö rekonstrueerimisel. Kuigi uue kodumaa toidud tungivad järjest enam igapäevasele toidulauale, jääb alles nostalgia kodumaa toidu suhtes.

Rukkileiva ja peotoitude puuduse või nende järele igatsemise kõrval leidis pagulaste puhul sõltumata nende asukohariigist sageli mainimist kondiitri- ja pagaritoodete erinevus Eesti omadest. Kõige paremini sobib seda ehk ilmestama üks Aleksandra Jaaksoni kiri Sally Sumborule, mille ta saatis 22.02.1962 Chicagost Seattle' isse:

Linda tütar Tabu käinud Torontos, söönud seal eesti kondiitrikooke ja öelnud, et tal olnud vanast ajast Eesti kookide maitse meeles, aga ta arvanud, et on seda ainult unes näinud, nüüd ta teab, et niisugusi kooke tõesti kuskil olemas oli ja ta ei võta Ameerika maiustusi enam suu sissegi. (IHRC, Sally Sumboru Papers)

\section{„Varjatud" eesti identiteet}

Immigrant on uuel maal kahe jõu pingeväljas: ühelt poolt tunneb ta vajadust säilitada vana ja tuttavat, teiselt poolt sunnib ümbritsev keskkond üle võtma võõraid kultuurielemente (Jürgenson 2011: 208). 1944. aasta pagulaste jaoks oli eestluse ja eesti kogukonna säilitamine üks olulisemaid ülesandeid, seda rõhutatakse nii intervjuudes kui kirjalikes mälestustes. Eestlaste jaoks muutus esmatähtsaks nn välisvõitlus ja keele ning (kõrg)kultuuri hoidmine.

Nagu tõdetakse raamatus "101 Eesti toitu ja toiduainet", on "söök nii loomulik igapäevaelu osa, et sageli on raske märgata selles kultuuri kõige laiemas tähenduses“ (Bardone, Kannike, Põltsam-Jürjo, Plath 2016: 8). Paljusid igapäevaseid tegevusi, sh toitu, ei pruugita identiteediga seostada. See, mida tagantjärele loetakse identiteedi oluliseks valdkonnaks, on tegelikult selle sees olnute jaoks nähtamatu ja tajumatu (Ray 2013: 363). Eesti toidul ei olnud pagulaspoliitikute ja kõneisikute silmis olulist positsiooni rahvusliku omapära alalhoidmisel. See ei liigitunud ei poliitilise võitluse alla ega sobitunud kultuuri. Toit oli liiga igapäevane: seda valmistati, 
söödi, armastati ja selle järele tunti puudust, kuid sellest ei räägitud, vähemalt mitte sõnavõttudes ja pidupäevakõnedes.

Aivar Jürgenson on uurinud nii Siberi kui Argentina eestlasi ja ta peatub mõlemas uurimuses põgusalt ka toidutraditsioonil. Siberi eestlastel püsis alguses eesti toidu söömise tava, kuna see sümboliseeris kodu(maad), kuid hiljem oli kodumaa juba asukohta vahetanud ja siis sidus eestipärane toit inimesi juba eesti kogukonnaga Siberis ja eraldas teistest rahvustest (Jürgenson 2006: 259). Argentina eestlasi käsitlevas uurimuses toob Jürgenson esile, et „,alguses oli eesti toitude söömine maitseküsimus, siis hiljem paigutusid eesti toidud kui selgelt teadvustatud eesti identiteedi osa ühtsesse eesti identiteedi sümbolväärtuste kogumisse, nad teadvustusid peamiselt tavanditoiduna rahvuslikel tähtpäevadel ja kalendripühadel“ (Jürgenson 2011: 210). Rahvustunnet ja selle hoidmist puudutavates väliseesti kogukondade avalikes tekstides (ajakirjandus, pidukõned jne) on eestipärane toit marginaalne, kuid intervjuude ja argielunäidete põhjal võib väita, et see on üks elujõulisemaid identiteediankruid. Eesti toitude valmistamine, võimaluse korral ostmine ja söömine on välismaal elavate eestlaste puhul tänaseni üks võimalusi end eestlasena identifitseerida ja tunda end asukohamaa eestlaste kogukonda kuuluvana.

Kui ma olen teiste juures käinud, ikka püütakse... keedetakse sülti ja niisukest asja. I...। Aga ikka eesti moodi see on, nagu öeldakse "päris Eesti“. Käime Torontos... ma käin, kui ma Torontosse lähen, siis ma toon eesti leiba. Seal on eesti pagarid ja eesti peent leiba ikka ostame sealt ja et seda teevad teised ka, mitte mina üksinda. Kõik võtavad säält, ikka käivad toomas jah. Ega me ikka pü̈̈ame ikka seda kodumaad ka ikka natuke alles hoida. (EA 277: 1/199)

„Põlvkondade vahetudes toimuvad diasporaakogukonna liikmete identiteediga reeglina suuremad muutused kui kodumaal elavatel inimestel. Alati pole siiski tegemist identiteedi nõrgenemisega, vaid pigem muutustega selle sisus ehk selles, mida peetakse meie-tunde jaoks kõige olulisemaks." (Ojamaa, Valk, Labi, KaruKletter 2008: 139) Jane Kalajärv on uurinud Toronto eestlaste kodukujundust ning selle seost eesti identiteediga. Ta toob välja, et pagulaste järeltulijate põlvkonna liikmetes tekitavad nostalgilisi tundeid asjad ja nähtused, mis kuulusid nende lapsepõlve juurde (Kalajärv 2011: 73). Maitsed ja toiduelamused on osa kodust, keskkonnast ja lapsepõlvemälestustest. Eriti juhul, kui füüsiline kodu kaotati, muutus toit üheks esmaseks kodutunde taasloomise vahendiks. Sõltuvalt sellest, milliste elementide kaudu eestipärasus on olnud kodus esindatud, tekitab see väliseestlaste järeltulijatele ka hilisemas eas assotsiatsioone oma Eesti päritoluga. Eesti toidu valmistamine kodus, ükskõik kas argi- või pidupäeval, on seega (sageli ehk seda selgelt teadvustamata) rahvusliku nüansi edasiandmine noorematele põlvedele.

Ema ütles, et nüüd läheme EV aastapäevale, aga mitte, et kas sa tahad minna. Eesti tähtpäevadel käimine oli nagu aamen kirikus. /.../ Minu lapsed teavad Eestist ainult seda, mis nad kodus kuulnud, teinud ja õppinud on. Mu tütred küpsetavad alati jõuluks piparkooke. (KV 1233: 8/78)

Lapsed praegu veel teevad kringlid (suured) sünnipäevadeks oma lastele ja ka tuttavatele. /.../ Rosolje oli ka, mida sageli sõime ja mida lapsed ikka veel edasi teevad oma külalistele ja peredele. Samuti liha, kala ja riisi, kapsa, singi pirukad nii väikesed kui ka suured. Samuti teen vahel "roosa mannad" ja "ujuvaid saari" ning "bubertit". (KV 1233: 11/120-121) 
Toronto Eesti Täienduskoolis õppeülesandena tehtud lühifilmis (Spence 2010) esitati kaasõpilastele küsimus „Mis teeb sind kui eestlast õnnelikuks?“ Üks vastus oli, et eesti sport (võrkpall). Teised vastused keerlesid kõik ümber toidu. Loeti üles selliseid eesti toite nagu pirukad (liha, porgand või kapsas sees), kringel (rosinasai), verivorst, kartulisalat, sült, (täidetud) muna, hapukapsas, pannkoogid, vastlakuklid, seapraad, rosolje, heeringas muna ja hapukoorega.

Paljudel kolmanda põlvkonna eestlastel on eesti keele oskus kadunud või väga napp. Samuti ei ole enam oluline samal moel võidelda eestluse püsimise eest, nagu seda tegi pagulaste esimene põlvkond ajal, mil Eesti oli Nõukogude Liidu poolt okupeeritud ja kardeti eestluse kadumist kodumaal. Ometi tunnetavad paljud väliseesti noored oma seotust Eestiga, ja eestipäraste toitude valmistamine ning söömine kodus või eestlaste üritustel eristab välismaal elavaid eestlasi ümbritsevatest rahvusgruppidest ning tekitab ühtsustunde teiste eestlastega.

Kuigi üle maailma on inimeste toidulaud muutunud palju rahvusvahelisemaks, on sageli traditsioonilisena säilinud nii pühadega kui pidupäevade tähistamisega seotud toidud. Nii ei kujuta enamik eestlasi ette jõule ilma verivorstideta. Neid ei tehta enam eraldi kodus, sest noorematel pole ilmselt seda oskustki ja tegemist on tänapäevases mõttes üsna mahuka tööga. Aga peaaegu igas suuremas eestlaste keskuses kogunetakse kas Eesti Majja või kellegi juurde koju, et võtta ette ühine suur verivorstitegu. Või võtab väiksem seltskond vorstiteo ette ja müüb neid Eesti Maja jõulubasaaril.

Toidul on oluline roll ka aktiivsel kollektiivse mälu loomisel. Lisaks konkreetsel hetkel saadavale kõhutäiele ja maitseelamusele annab see võimaluse siduda omavahel kaks aspekti. Esiteks aistinguline maitsemälestus ja toidu kaudu esitatud nostalgiline suhtumine minevikus toimunusse. Teiseks tuleviku mälestuste loomine käesoleva hetke planeerimise teel (Sutton 2008). Kui välismaal elavad eestlased söövad eesti toitu, võib jutt üsna kergelt minna nii perekonnale kui eestlastele laiemalt omaste toiduharjumuste peale. Toidust rääkimise kaudu jõutakse sageli ka mõne lahkunud pereliikmete või varasema Eesti elukorralduse meenutamiseni. Teisest küljest on jõulude ootuses alati oluline osa toiduootusel ja planeerimisel - nii aga luuakse uusi mälestusi tuleviku tarvis. „Tavanditoitude valmistamine ja söömine on osa immigrantide maailma katkestatuse ületamise protsessist. Kui vanemad teevad Eesti toite, siis loovad need justkui silla vanemate eluilmaga" (Jürgenson 2011: 359). Tekib põlvkonnaülene kultuuriline nostalgia aja ja koha suhtes, mida ise otseselt kogetud ei ole. See omakorda loob eelduse kollektiivse identiteedi kujunemisele pühadetoidu kaudu.

\section{Kokkuvõte}

1944. aastal Eestist lahkunud pagulased kohtusid uuel asukohamaal (Rootsi, Saksamaa, Inglismaa, Austraalia, USA, Kanada) harjumatute toiduainete, toitude ja toiduvalmistamise viisidega. Igal maal olid toidud natuke erinevad, kuid esimestest toidukogemustest rääkides või kirjutades kurdetakse alati eestipäraste toitude puudumise üle. Inimeste argieluliste ootuste ja tegevuse kontekstis tähendas see 
kultuurilist kokkupõrget põgenemisel kaasvõetud harjumuste ja uuel asukohamaal kogetu vahel.

Eestipärase toidu puudumine kohalikus toidukultuuris viis vajaduseni ise valmistada nii igapäevaseid (nt leib, hapukapsas) kui pühade ja pidulike sündmustega seotud roogasid (nt sült, rosolje, kringel). Enamasti olid toiduvalmistajateks naised, kes käisid perele elatise teenimiseks ka palgatööl.

Pagulaste esimesele põlvkonnale tähendas eestipärane toit kodumaa toitu, mis tekitas otsese seose mahajäänud koduga, mida meenutati üha suurema nostalgiaga. Pagulaste järeltulijate põlvkonna liikmete jaoks on maitsed ja toiduelamused osa kodust, keskkonnast ja lapsepõlvemälestustest.

Muuseumi arhiivis leiduvate intervjuude ja küsitluslehtede vastuste ning välitöödel saadud kogemuse põhjal võib järeldada, et eestipärane toit on väliseesti kogukondade igapäevases elus üks elujõulisemaid identiteediankruid. Eesti toitude valmistamine, võimaluse korral ostmine ja söömine on välismaal elavate eestlaste puhul tänaseni üks võimalusi end eestlasena identifitseerida ja lõimuda asukohamaa eestlaste kogukonda.

\section{Allikad}

Eesti Rahva Muuseum:

ERM EA = Etnograafiline arhiiv 262, 263, 264, 277, 283

ERM KV 1005 = Korrespondentide vastuste arhiiv, küsimusleht nr 203, Põgenemine kodumaalt. Esimene aastakümme paguluses.

ERM KV 1006 = Korrespondentide vastuste arhiiv, küsimusleht nr 203, Põgenemine kodumaalt. Esimene aastakümme paguluses.

ERM KV 1008 = Korrespondentide vastuste arhiiv, küsimusleht nr 203, Põgenemine kodumaalt. Esimene aastakümme paguluses.

ERM KV 1009 = Korrespondentide vastuste arhiiv, küsimusleht nr 203, Põgenemine kodumaalt. Esimene aastakümme paguluses.

ERM KV 1010 = Korrespondentide vastuste arhiiv, küsimusleht nr 203, Põgenemine kodumaalt. Esimene aastakümme paguluses.

ERM KV 1012 = Korrespondentide vastuste arhiiv, küsimusleht nr 203, Põgenemine kodumaalt. Esimene aastakümme paguluses.

ERM KV 1013 = Korrespondentide vastuste arhiiv, küsimusleht nr 203, Põgenemine kodumaalt. Esimene aastakümme paguluses.

ERM KV 1014 = Korrespondentide vastuste arhiiv, küsimusleht nr 203, Põgenemine kodumaalt. Esimene aastakümme paguluses.

ERM KV 1015 = Haas, Heinrich „Mälestusi võõrsilt" , 1944-68

ERM KV 1016 = Korrespondentide vastuste arhiiv, küsimusleht nr 203, Põgenemine kodumaalt. Esimene aastakümme paguluses.

ERM KV 1090 = Moks, Taimi-Ene „Mälestused, päevik, dokumendid 1955-1955”

ERM KV 1232 = Korrespondentide vastuste arhiiv, küsimusleht nr 213, Väliseestlased 19552000

ERM KV 1233 = Korrespondentide vastuste arhiiv, küsimusleht nr 213, Väliseestlased 19552000

Etti Sirg Papers 
IHRC Archives, University of Minnesota:

Sally Sumboru Papers

\section{Kirjandus}

Aun, Karl. 1985. The Political Refugees. A History of the Estonians in Canada. Toronto: McClelland and Stewart.

Bardone, Ester; Kannike, Anu; Põltsam-Jürjo, Inna; Plath, Ulrike. 2016. 101 Eesti toitu ja toiduainet. Tallinn: Varrak.

Holak, Susan L. 2014. From Brighton beach to blogs: exploring food - related nostalgia in the Russian diaspora. - Consumption Markets \& Culture, 17: 2, 185-207.

Jürgenson, Aivar. 2006. Siberiga seotud. Eestlased teisel pool Uuraleid. Tallinn: Argo.

Jürgenson, Aivar. 2011. Ladina rahva seas. Argentiina ja sealsed eestlased. Tallinn: TLÜ Ajalooinstituut ja Argo.

Kalajärv, Jane. 2011. Kultuuriidentiteet ja koduinterjöör Kanada eestlaste näitel. Magistritöö. Tallinn: Eesti Kunstiakadeemia.

Kool, Ferdinand. 1999. DP Kroonika. Eesti pagulased Saksamaal 1944-1951. Lakewood: Eesti Arhiiv Ühendriikides.

Kumer-Haukanõmm, Kaja. 2009. Eestlaste põgenemine Saksmaale. - Hallik, Terje; Kukk, Kristi; Laidla, Janet (toim). Eestlaste põgenemine Läände Teise maailmasõja ajal. Artiklid ja elulood. Tartu: korp! Filiae Patriae, 13-53.

Kõiva, Mare. 2012. Adapteerumisjutud Austraalia eestlaste näitel. - Mäetagused 50, 113-140.

Kõll, Anu Mai. 2009. Eesti põgenike toimetulekust Rootsis naiste perspektiivist. - Hallik, Terje; Kukk, Kristi; Laidla, Janet (toim). Eestlaste põgenemine Läände Teise maailmasõja ajal. Artiklid ja elulood. Tartu: korp! Filiae Patriae, 65-84.

Madise, Juhan. 1966. Emigratsioon Saksamaalt. - Maasing, Richard jt (toim). Eesti saatusaastad 1945-1960. IV osa, Poliitilised põgenikud. Stockholm: EMP, 179-189.

Merivoo-Parro, Maarja. 2010. New Yorgi Eesti Haridusselts ja pagulased. Magistritöö. Tallinn: Tallinna Ülikool.

Noorhani, Piret; Pitsi, Kaisa; Reinvelt, Riina. 2014. Toidutoojad. Ajaloolised toiduärid Torontos. Dokfilm. Toronto : VEMU/Estonian Studies Centre; Tartu: Eesti Rahva Muuseum.

Postiglione, Nadia. 2010. It was just horrible. The food experience og immigrants in 1950s Australia. - History Australia, 7:1, 09.1-09.16.

Ojamaa, Triinu; Valk, Aune; Labi, Kanni; Karu-Kletter, Kristel. 2008. Muusika osast diasporaaeestlaste identiteedis. - Anniste, Kristi; Kumer-Haukanõmm, Kaja; Tammaru, Tiit (toim). Sõna jõul. Diasporaa roll Eesti iseseisvuse taastamisel. Tartu: Tartu Ülikooli Kirjastus, 137-155.

Raag, Raimo. 2009. Eestlaste põgenemine Rootsi Teise maailmasõja ajal. - Hallik, Terje; Kukk, Kristi; Laidla, Janet (toim). Eestlaste põgenemine Läände Teise maailmasõja ajal. Artiklid ja elulood. Tartu: korp! Filiae Patriae, 55-63.

Ray, Krishnendu. 2013. Food and Identity. - Anne Murcott, Warren Belasco, Peter Jackson (ed). The Handbook of Food Research. London: Bloomsbury, 363-376.

Saar, Edgar. 1998. Põgenemine kodumaalt. Esimene aastakümme paguluses. ERMi küsitlusleht nr 203.

Saar, Edgar. 2000. Eesti pagulaste kohanemine Inglismaal. - Eestlane ja tema maa. Konverentsi "Kodumaa ja kodupaik: eestlase territoriaalne identiteet" (16.-17.11.1999) materjale. Tallinn: Ajaloo Instituut, 98-108.

Saar, Edgar. 2002. Väliseestlased 1955-2000. ERMi küsitlusleht nr 213.

Spence, Krista. 2010. Estonians: Are They Ever Happy? Lühifilm. Esto 4 Class, Toronto Eesti Kool. 
Sutton, David. 2006. Cooking Skill, the Senses, and Memory: The Fate of Practical Knowledge. - Elizabeth Edwards, Chris Gosden, Ruth B. Philips (eds.). Sensible objects. Colonialism, Museums and Material Culture. Oxford: Berg Publishers, 87-118.

Sutton, David. 2008. A Tale of Easter Ovens: Food and Collective Memory. - Social Research 75:1, 157-180.

Valk, Aune; Karu, Kristel. 2002. Eesti identiteet Eestis ja Rootsis. - Aune Valk (koost). Eesti ja eestlased võrdlevas perspektiivis: kultuuridevahelisi uurimusi 20. sajandi lõpust. Tartu: Tartu Ülikooli Kirjastus, 125-141.

Riina Reinvelt on ERMi peavarahoidja. Kaitsnud Tartu Ülikoolis etnoloogia magistrikraadi 2004. aastal. Uurimisvaldkonnad: ingerisoomlased, Eesti diasporaa, küüditamine nõukogude ajal, eluloolised allikad. Kureerinud mitmeid näitusi (nt „Kuue samba kutse. Naisena ülikoolis“, „Eesti uhkus. Tehtud Eestis“, „1944. Meri läände“, „Külatänavalt punasele vaibale. 100 aastat rahvuslikku moodi“).

\section{Summary: Our food and theirs: the 1944 émigrés' food experience based on Estonian National Museum sources}

\section{Riina Reinvelt}

In the summer and autumn of 1944, as the Soviet front drew nearer, thousands of Estonians fled across the Baltic Sea to Finland, Sweden and Germany. The total number of those who fled has been estimated at 70,000-90,000 people. Of them, 50,000 Estonians made it to Germany and 28,000 Estonians to Sweden. Later a number of them emigrated further to the US, Canada, Australia and England. In their new adopted homes, the émigrés encountered unaccustomed food ingredients, dishes and food preparation methods. These items varied slightly in all countries, but a theme that was a constant for émigrés when they wrote or talked about their experiences with food was the lack of Estonian-type foods. In the context of people's everyday expectations and practices, this meant a cultural clash between the habitual practices they carried with them when they became refugees and the experiences in their new homelands.

The lack of Estonian food in the local food culture led to the need to prepare the dishes themselves - both everyday staples (such as bread and sauerkraut) and fare associated with special occasions and holidays (head cheese or sült, the beet and potato salad called rosolje and the sweet fruited bread kringel). The food preparers were mainly women, and women also typically also hold a regular job to earn a living for the family.

The first generation of émigrés saw Estonian-style food as the food of their homeland, which fostered a direct link to the home they had left; attitudes toward it became increasingly nostalgic. For the first generation of descendants of the 
émigrés, the flavours and food experiences are a part of home, environment and childhood memories.

On the basis of the interviews and answers on questionnaire forms in the museum archive as well as the experiences gained in field work, we can conclude that in everyday practice, Estonian-style food is one of the most vital anchors of identity for émigré Estonian communities. The preparation of Estonian foods, the seeking out of such food from stores and consumption of Estonian food remains for the Estonian diaspora a way to identify as Estonian and adapt into the community of Estonians in their country of location.

\section{Резюме: Своя и чужая еда: связанный с едой опыт беженцев 1944 года на базе источников ЭНМ}

\section{Рийна Рейнвелт}

Летом и осенью 1944 года, спасаясь от наступающих советских войск, через Балтийское море в Финляндию и Швецию бежали тысячи эстонцев. Предполагается, что количество перебравшихся во время Второй мировой войны на запад составляет 70 000-90 000 человек, из них в Германию прибыло примерно 50000 и в Швецию около 28000 эстонцев. Впоследствии эстонцы переселялись в США, Канаду, Австралию и Англию. В новых местах поселений беженцы столкнулись с непривычными продуктами питания, блюдами и способами приготовления пищи. В каждом месте блюда немного отличались, но рассказывая или описывая свое первое впечатление от еды всегда сетовали на отсутствие эстонской еды. В контексте повседневных ожиданий людей и практик это означало культурное столкновение между взятыми с собой с родины привычками и опытом, полученным в новых местах поселения.

Отсутствие в местной культуре питания привычной эстонской еды привело к необходимости самим готовить как повседневную еду (напр., хлеб, квашеная капуста), так и связанные с праздничными событиями блюда (напр., холодец, розолье, крендель). Большей частью еду готовиди женщины, которые в то же время, работая, зарабатывали средства к жизни

Дия первого поколения беженцев эстонская еда означала еду, которую ели на родине, создающую прямую связь с оставденным домом, отношение к которому становилось все более ностальгическим. Для членов следующего поколения беженцев вкусы и связанные с едой впечатления явдяются частью дома, среды и детских воспоминаний.

На базе имеющихся в архивах музея интервью и ответов на анкеты, а также полученного в ходе экспедиционных работ опыта, можно сделать вывод о том, что эстонская еда в повседневной практике общин зарубежных эстонцев является одним из самых жизнеспособных якорей идентитета. Приготовление эстонской еды, покупка по возможности в магазинах и употребление ее в пищу остается и по сегодняшний день для живущих за границей эстонцев одной из возможностей идентифицировать себя в качестве эстонцев и адаптироваться в эстонскую общину страны проживания. 